DOI 10.1590/S0104-64972015002324

\title{
A new species of Trichorhina Budde-Lund, 1908 (Isopoda: Oniscidea: Platyarthridae) from Paraná caves, southern Brazil
}

Ivanklin Soares Campos-Filho*, Kleber Makoto Mise and Gisele Cristina Sessegolo

(ISC-F) Istituto per lo Studio degli Ecosistemi, Consiglio Nazionale delle Ricerche, Via Madonna del Piano 10, 50019, Sesto Fiorentino (Firenze), Italy. E-mail: ivanklin.filho@gmail.com. ${ }^{*}$ Corresponding author.

(KMM; GCS) Eccosistema Consultoria Ambiental. Rua Dionízio Baglioli, 111. 81510-540 Curitiba, Paraná, Brazil. E-mails: kleber.mise@ecossistema.bio.br; gisele.sessegolo@terra.com.br

ZOOBANK: http://zoobank.org/urn:lsid:zoobank.org:pub:26501F88-D8F4-4D56-9D12-BB7AC936FBE0

\begin{abstract}
The genus Trichorhina Budde-Lund, 1908 in Brazil includes 22 described species, four of which occur in caves. The present work aims at describing the first cave species for the state of Paraná. Trichorhina kaingangi n. sp. was collected in Água Boa cave, municipally of Almirante Tamandaré, and Ermida Paiol do Alto cave, municipally of Adrianópolis, both in the Açungui karst area.
\end{abstract}

Key words: Crustacea, terrestrial isopods, Açungui karst group, Neotropic.

\section{INTRODUCTION}

Until 2004, approximately 300 species of troglobiotic terrestrial isopods (Oniscidea) were known worldwide, mostly described from caves in the northern hemisphere (Taiti, 2004). Biospeleological surveys conducted in the last decades in Australia, Asia and South America have partly modified this scenario and to date 331 troglobiotic Oniscidea species are known (Taiti and Gruber, 2008; Taiti and Xue, 2012; Tabacaru and Giurginca, 2013; Campos-Filho et al., 2014; Taiti 2014; Souza et al., 2015; Taiti and Wynne, 2015). This number is certainly not exhaustive, since a large amount of material has been recently collected and many new taxa are still waiting formal descriptions. The taxonomic impediment has been the major problem for subterranean research development and cave conservation (Bichuette and Trajano, 2010; Cordeiro et al., 2014).

Nowadays about 170 species of terrestrial isopods are known from Brazil, 29 of which are recorded from cave environments (Souza-Kury, 1993; Souza et al., 2006; 2010; 2015; CamposFilho et al., 2014; 2015). Thirteen species are known from the state of Paraná, but none of them was recorded from caves. Only two species have been recorded exclusively from the state of Paraná: Benthana itaipuensis Campos-Filho and Araujo, 2011 from Foz do Iguaçu, and Benthana guayanas Campos-Filho, Costa and Araujo, 2013 from Morretes and São João da Graciosa (SouzaKury, 1998; Campos-Filho and Araujo, 2011; Costa et al., 2014; Campos-Filho et al., 2013; 2015).

The genus Trichorhina Budde-Lund, 1908 in Brazil includes 22 species, including the pantropical Trichorhina tomentosa (Budde-Lund, 1908) and Trichorhina heterophthalma Lemos de Castro, 1964. Four species of Trichorhina are known to occur in caves: Trichorhina guanophila Souza-Kury, 1993 from the state of Bahia, Trichorhina yiara CamposFilho, Araujo and Taiti, 2014 and Trichorhina curupira Campos-Filho, Araujo and Taiti, 2014 from the state of Pará, and Trichorhina anhanguera Campos-Filho, Araujo and Taiti, 2014 from the state of Minas Gerais (Schmalfuss, 2003; Araujo and Almerão, 2007; Souza et al., 2011; CamposFilho et al., 2014).

In the present work the first cave-dwelling species of Trichorhina from the state of Paraná is described. The material was collected in Água 
Boa cave, municipally of Almirante Tamandaré, and Ermida Paiol do Alto cave, municipally of Adrianópolis, both located in the Açungui karst area.

\section{Material and Methods}

Specimens are stored in 75\% ethanol and identifications are based on morphological characters. Some specimens were dissected and the appendages and pereonites were mounted in micropreparations. Drawings were prepared using a camera lucida. The coordinates of the noduli laterales were obtained and figured as in Vandel (1962). The type material is deposited at Museu de História Natural de Capão da Imbuia (MHNCI), Curitiba, state of Paraná, Brazil, Museu de Zoologia, Universidade de São Paulo (MZUSP), São Paulo, state of São Paulo, Brazil, and Natural History Museum, Section Zoology 'La Specola', Florence, Italy (MZUF).

\section{Study Area}

The Açungui karst area is composed of three stratigraphic formations: Capiru, Votuverava and Antinha (Fiori and Gaspar, 1993). The geomorphological evolution of Açungui karst area comprises three main events: (1) the creation of the Purunã Surface; (2) the creation of the Alto Iguaçu Surface; and (3) the opening of the Ribeira River Valley (Alto Ribeira basin), dated from Lower Miocene (Ab'Saber and Bigarella, 1961). The Açungui karst area developed in a uniform geological, geomorphological and climatic environment (Nascimento et al., 2010). The two caves investigated are located in the Alto Ribeira basin, ca. $70 \mathrm{~km}$ apart, near limestone extraction areas (Fig. 1).

The Água Boa cave belongs to the Capiru Formation, composed mainly of dolomitic limestone. The cave is about $110 \mathrm{~m}$ long, very moist with water dripping from the ceiling and forming water puddles in the middle portion. It has two entrances, one of which is used by the mining company which explores the area. The main organic substrates are composed of vegetal matter (entrance and twilight zone) and guano (aphotic zone) of the hematophagous bat Desmodus rotundus

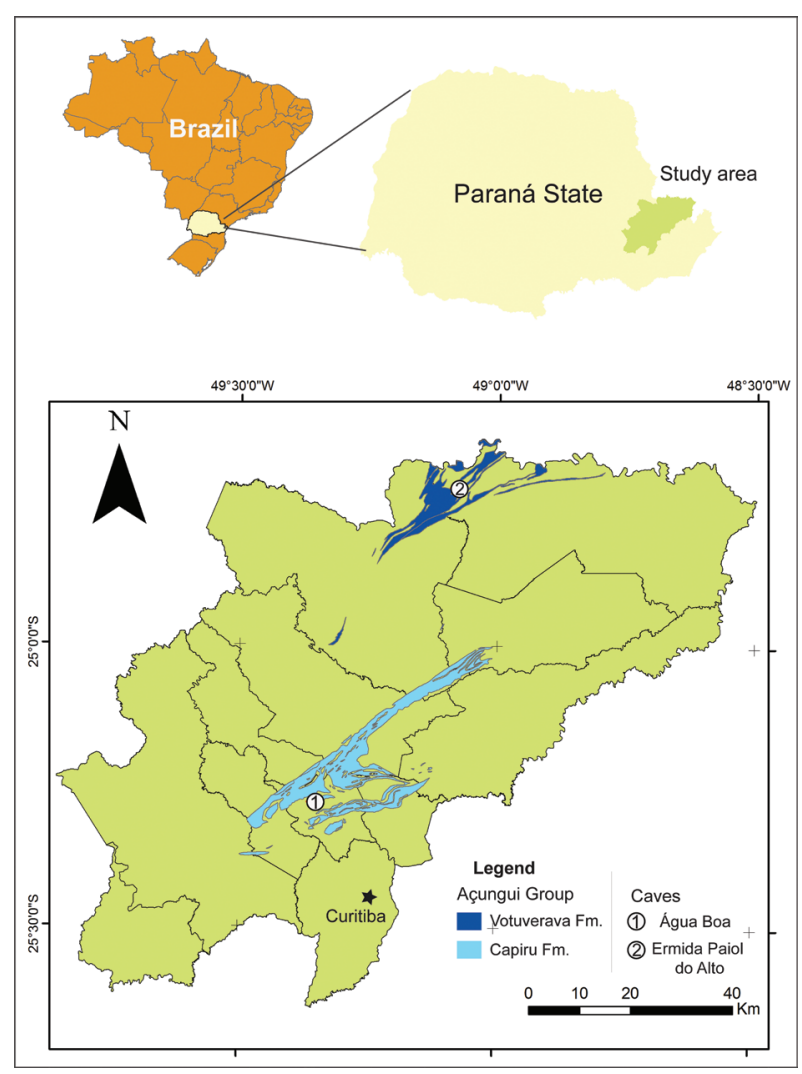

Figure 1. Map of Açungui karst locating the Votuverava and Capiru formations. Numbers indicate cave position. Legend: Fm $=$ formation.

(E. Geoffroy, 1810). The bat population in the cave has recently suffered a significant reduction due to chemical control to prevent rabies (Arnone, 2008). Most of the bat guano is old and dry, indicating resource depletion.

The Ermida Paiol do Alto cave is located in the Votuverava formation, composed of calcite limestone. The cave is about $140 \mathrm{~m}$ long, with a downhill orientation, contributing to accumulate organic material with different levels of decomposition from the entrance to the twilight zone. The cave has two main conduits and no evidence of hydric activity. Bat guano, probably of the hematophagous bat Diphylla ecaudata Spix, 1823 , is present in the twilight and aphotic zones. Fungi are found throughout the cave on the walls and over the bat droppings.

\section{SystemaTICS}

Family Platyarthridae Verhoeff, 1949

Genus Trichorbina Budde-Lund, 1908 
Type species. Bathytropa thermophila Dollfus, 1896 [= Trichorhina tomentosa (Budde-Lund, 1893)] by original designation.

Diagnosis. Schmidt (2002) and Souza et al. (2011).

\section{Trichorbina kaingangi n. sp. Campos-Filho, 2015}

(Figs. 2-4)

Type material. Holotype Paraná: 1 ते, Adrianópolis, Ermida Paiol do Alto cave (2443'10"S 4905'4”W, 25/II/2014, leg. K.M. Mise, MHNCI 4485). Paratypes Paraná: same data as holotype, 1 त (26/II/2014, leg. Tatiana Portella et al., MHNCI 4486), 1 đ (26/II/2014, leg. Tatiana Portella et al., MHNCI 4487), 1 ô, 1 q (26/II/2014, leg. Tatiana Portella et al., MZUSP 33990), 1 $\lesssim$ (on micropreparations) (MHNCI 4488), 1 q (26/ II/2014, leg. Tatiana Portella et al., MHNCI 4489), 2 (26/II/2014, leg. Tatiana Portella et al., MHNCI 4490), 1 q (26/II/2014, leg. Tatiana Portella et al., MHNCI 4491), 1 ( leg. Tatiana Portella et al., MHNCI 4492), 1 ๙ (MZUSP 33991), 1 (MZUSP 33992), 1 ô, 1 ㅇ (MZUSP 33993), 2 ๙ึ, 2 q (MZUF 9614), 1 ㅇ, Almirante Tamandaré, Água Boa Cave (2516'43"S 4921'29”W, 07/IV/2014, leg. C. Souza, MHNCI 4493), 1 q, Almirante Tamandaré, Água Boa Cave (leg. C. Souza, MHNCI 4494).

Etymology. The new species is named after the native people Kaingang inhabiting the Brazilian states of São Paulo, Paraná, Santa Catarina and Rio Grande do Sul.

Description. Maximum body length $5 \mathrm{~mm}$. Body stout with pereon epimera gradually directed backwards (Fig. 2A). Colourless body. Dorsum surface covered with fan-shaped scale-setae with anastomosed surface (Fig. 2B). One line of noduli laterales inserted close to posterior margins and more or less at same distance from lateral margins of pereonites (Fig. 2B); b/c and d/c coordinates as in Fig. 2C, D. Cephalothorax with well-developed rounded lateral lobes, suprantennal line straight, no frontal line; eyes absent (Fig. 2E, F). Pleon with outline continuous with that of pereon; epimera of pleonites 3-5 well-developed (Fig. 2A). Pleotelson triangular, lateral margins slightly concave and acute apex (Fig. 2G). Antennula of three articles, distal article with nine aesthetascs (Fig. 2H). Antenna when extended posteriorly, reaching posterior margin of pereonite 1; setose longitudinal groove for the water-conducting system (sensu Schmalfuss, 1998) from base of peduncle to distal article of flagellum; flagellum as long as fifth article of peduncle, second article about three times as long as first with two aesthetascs on distal portion, apical organ short with long free sensillae (Fig. 2I). Mandible with molar penicil of about six branches, left mandible with $2+1$ penicils, right mandible with $1+1$ penicils (Fig. 2J, K). Maxillula inner branch with two penicils; outer branch with $4+5$ teeth, all simple (Fig. 2L). Maxilla with setose and bilobate apex; outer lobe about three times as wide as inner lobe, subquadrate and distal margin slightly rounded (Fig. 2M). Maxilliped basis rectangular bearing sparse scale-setae; endite subrectangular, medial seta surpassing distal margin (Fig. 2N). Uropod outer margin grooved bearing glandular pores, exopod slightly longer than endopod (Fig. 3A). Pereopod sternal setae with cleft apex; pereopod 1 with antennal grooming brush transverse reaching median margin of carpus; dactylus with long inner claw, ungual seta with simple apex reaching median portion of outer claw, dactylar seta with simple apex reaching tip of outer claw (Fig. 3B).

Male. Pereopod 1-3 merus and carpus with brush of setae on sternal margin; carpus 1 distal seta with double-serrate apex (Fig. 3B). Pereopod 7 merus and carpus with sternal setae slightly sparse, ischium sternal margin straight and distal margin bearing three large setae (Fig. 3C). Genital papilla as in Fig. 3D. Pleopod 1 exopod ovoidal, twice as broad as long, with rounded distal part; endopod three times as long as exopod, distal part acute, inner margin bearing minute setae along the margin (Fig. 3E). Pleopod 2 exopod triangular, outer margin concave bearing four setae; endopod slightly longer than exopod (Fig. 3F). Pleopod 3 and 4 exopods as in Fig. $3 \mathrm{G}$, H. Pleopod 5 exopod triangular, outer margin convex bearing nine setae (Fig. 3I). 


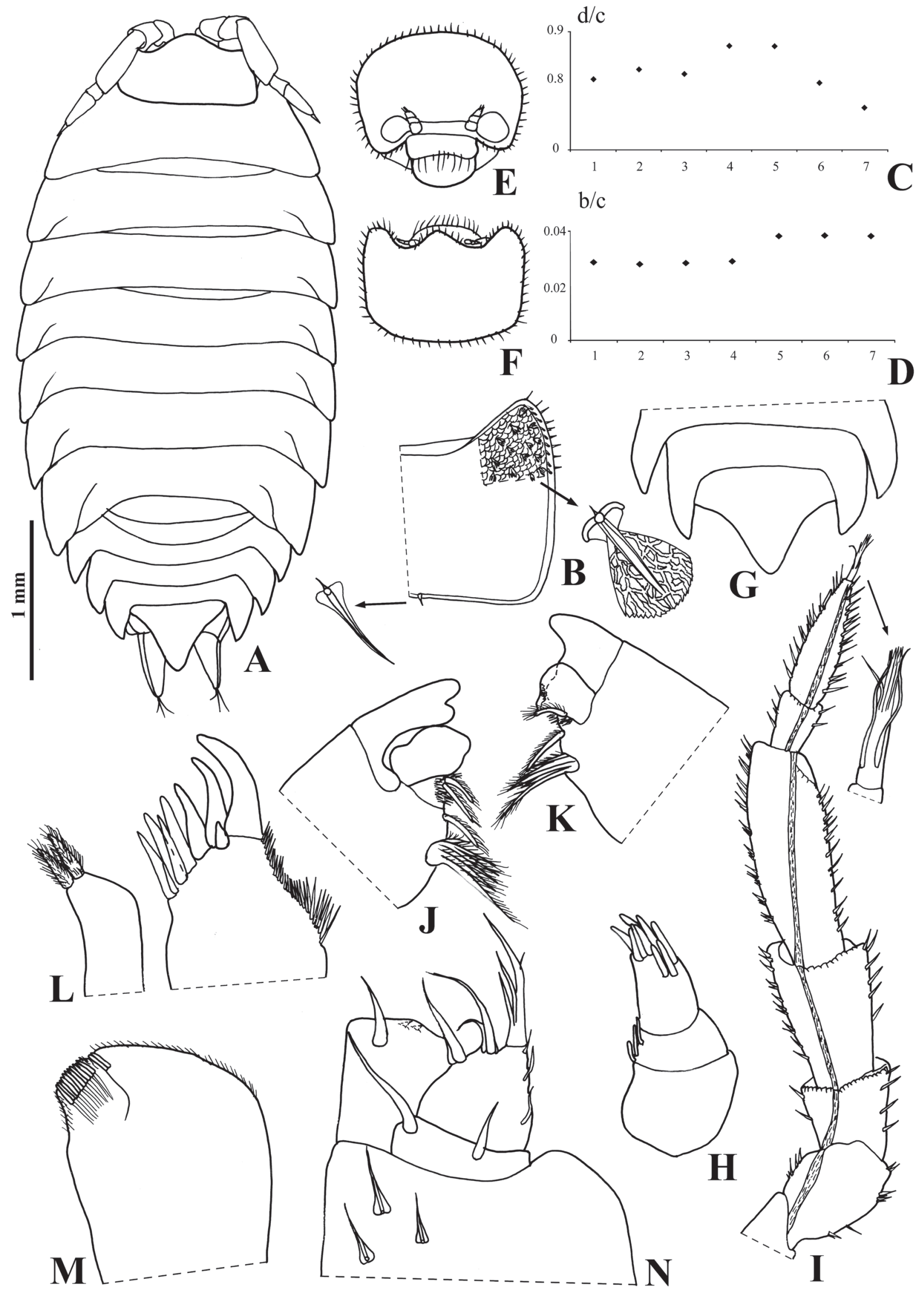

Figure 2. Trichorhina kaingangi n. sp. (male paratype). A, habitus; B, pereonite 1, scale-seta and nodulus laterales; C, noduli laterales $\mathrm{d} / \mathrm{c}$ coordinates; D, noduli laterales b/c coordinates; E, cephalothorax, frontal view; F, cephalothorax, dorsal view; G, pleonites 4, 5 and pleotelson; H, antennula; I, antenna; J, left mandible; K, right mandible; L, maxillula; $M$, maxilla; N, maxilliped. 


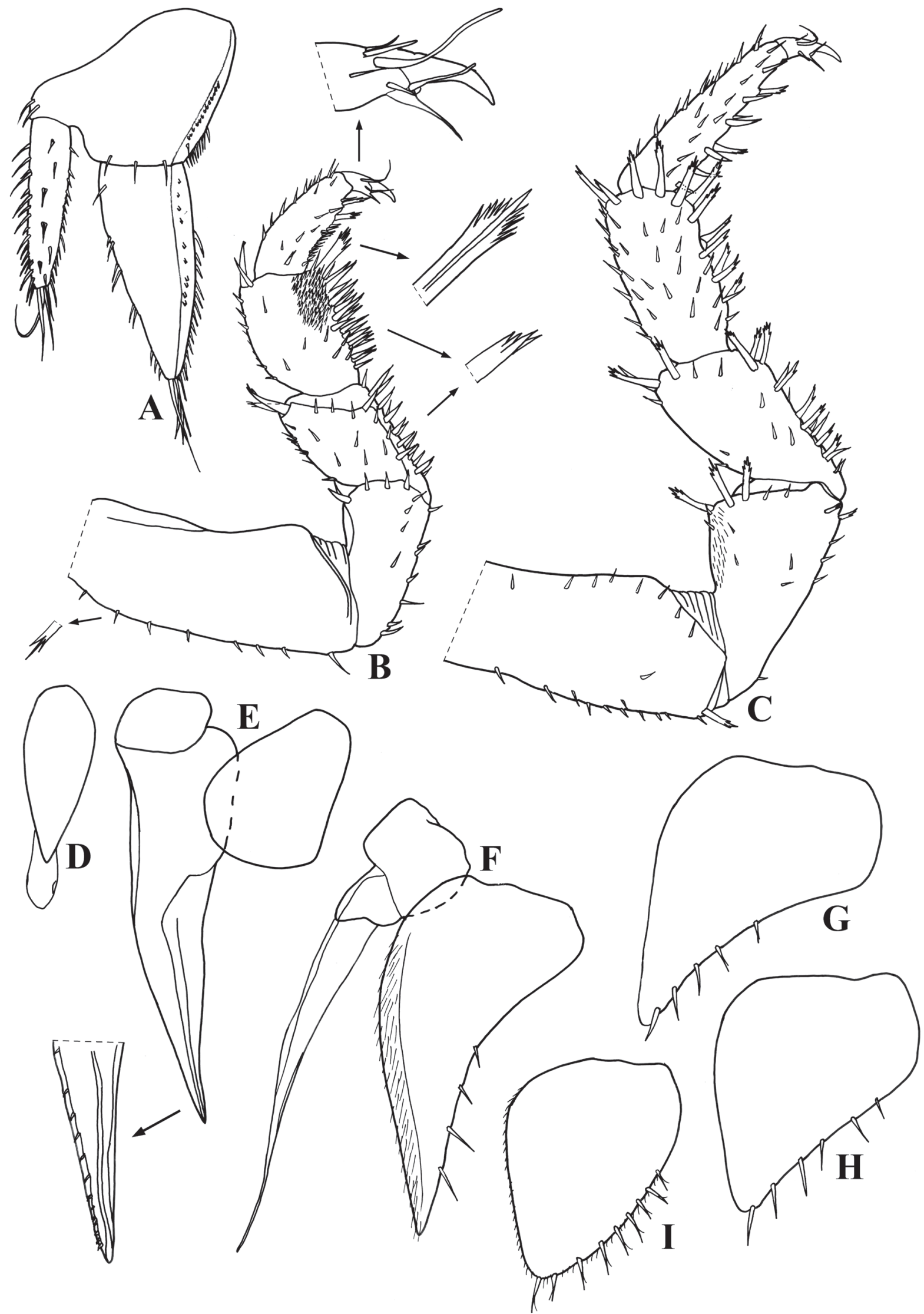

Figure 3. Trichorhina kaingangi n. sp. (male paratype). A, uropod; B, pereopod; C, pereopod 7; D, genital papilla; E, pleopod 1; F, pleopod 1; G, pleopod 3 exopod; H, pleopod 4 exopod; I, pleopod 5 exopod. 
Remarks. In the absence of eyes Trichorhina kaingangi n. sp. resembles Trichorhina caeca Vandel, 1952 (Venezuela: El Junquito), Trichorhina anhanguera (Brazil: state of Pará) and Trichorhina brasilensis Andersson, 1960 (Brazil: state of Santa Catarina). It is distinguished from all these species by the stout body shape, different shape of dorsal scale-setae (fan-shaped with anastomosed surface vs. rib-shaped surface) and different shape of the male pleopod 1 exopod; from $T$. caeca also in the shape of the pleotelson (lateral margins concave and acute apex vs. lateral margins slightly convex and rounded apex); from $T$. anhanguera in the mandible with molar penicil dichotomized (vs. simple); and from $T$. brasilensis and T. caeca in the maxillular outer endite with simple teeth (vs. cleft) on the inner set.

As mentioned by Campos-Filho et al. (2014), the assumption of troglobiotic condition in species of Trichorhina is complicated, because most representatives have an endogean way of life, with similar morphological adaptations to troglobiotic forms, i.e. eye reduction/absence and body depigmentation. It is well known that convergent or parallel phenotypic evolution exists between animals living in deep soil and in caves, which can obscure taxonomic relationships (Wilkens and Strecker, 2003; Juan et al., 2010; Campos-Filho et al., 2014). The new species has been found in caves, but more extensive collections in contiguous endogean habitats, which are not usually performed properly in biospeleological surveys, may prove their occurrence outside caves, suggesting a troglophilic rather than a troglobiotic condition.

The Brazilian laws (BRASIL, 1990; 2008) guarantee cave preservation when a cave reaches the maximum relevance, and this is only possible when there are rare or endemic troglobiotic species (e.g. Cardoso et al., 2014; Campos-Filho et al., 2014). Thus, although laws protect at least part of the obligate cave fauna, conservation acts cannot come into effect if species remain undescribed. For this reason, taxonomic studies of subterranean species in Brazil are of crucial importance for the preservation of both the environment and the species, and any delay in taxonomic research in caves may yield permanent loss of biodiversity, even before the species are discovered and described (e.g. Bichuette and Trajano, 2005; Fišer et al., 2013; Campos-Filho et al., 2014).

Ecological considerations. In Ermida Paiol do Alto the species occurs throughout the cave, from photic to aphotic zones. The specimens were found on the cave floor and over bat guano, in rainy and dry seasons (Fig. 4). In Água Boa cave the specimens were collected at the entrance and twilight zones, on the cave floor and over decomposing vegetable matter, both in rainy and dry seasons. Trichorhina kaingangi n. sp. was collected together with the introduced species Miktoniscus medcofi (Van Name, 1940) (19, MHNCI 4881), which is widely distributed from southern and central USA, Mexico, and Brazilian states of Amapá, Pará, Rio de Janeiro, São Paulo and Rio Grande do Sul (Lemos de Castro, 1971; Araujo and Bueno, 1998; Campos-Filho et al., 2014).

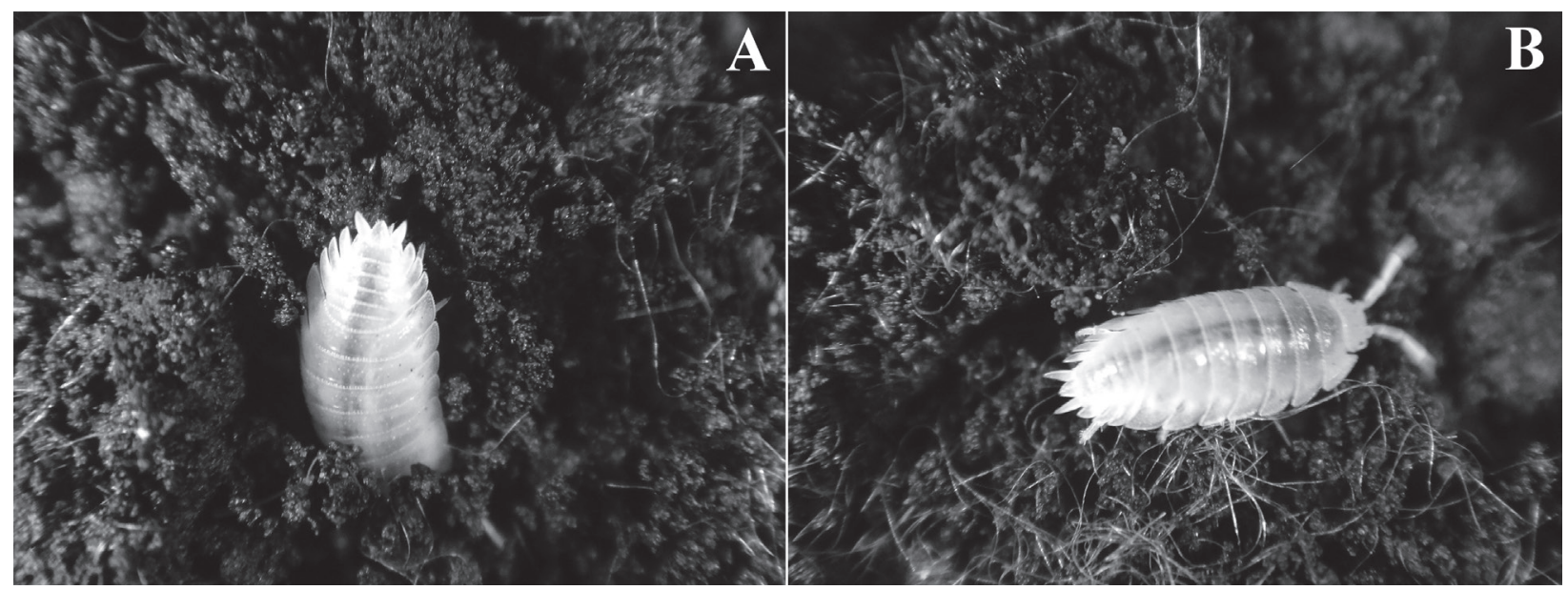

Figure 4. Trichorhina kaingangi n. sp.. A, B, specimens from Gruta Ermida Paiol do Alto, Adrianópolis, Paraná. 


\section{ACKNOWLEDGMENTS}

We are grateful to Profs Marcos Tavares and Maria José from MZUSP, and Odete L. Lopes from MHNCI for assisting with depositing material; CNPq (Conselho Nacional de Desenvolvimento Científico e Tecnológico) for the scholarship granted to ISC-F (PDE 204468/2014-0); José Eduardo Becker for helping with maps and geological information; Cláudio Souza, Williams Munguia Paredes and Barbara Nogueira for the assistance during the collecting.

\section{REFERENCES}

Ab'Saber, A.N. and Bigarella, J.J. 1961. Consideraçóes sobre a geomorfogênese da serra do Mar no Paraná. Boletim Paranaense de Geografia, 4/5: 94-110.

Andersson, A. 1960. South American terrestrial isopods in the collection of the Swedish State Museum of Natural History. Arkiv for Zoologi, 12: 537-570.

Araujo, P.B. and Almerão, M. 2007. Nova espécie de Trichorhina (Isopoda, Oniscidea, Platyarthridae) do Brasil. Iheringia, Série Zoologia, 97(2): 219-222.

Araujo, P.B. and Bueno, A. 1998. Novos registros de isópodos terrestres do sul do Brasil: Porcellionidae e Trichoniscidae (Crustacea, Oniscidea). Nauplius, 6: 185-186.

Arnone, I.S. 2008. Study of the community of bats of a carstic area of Alto Ribeira -SP. A comparison with 1980. Universidade de São Paulo - USP, São Paulo, Brazil, Master Dissertation (abstract in English). 119 p. [Unpublished].

Bichuette, M.E. and Trajano, E. 2005. A new cave species of Rhamdia Bleeker, 1858 (Siluriformes: Heptapteridae) from Serra do Ramalho, northeastern Brazil, with notes on ecology and behavior. Neotropical Ichthyology, 3(4): 587-595.

Bichuette, M.E. and Trajano, E. 2010. Conservation of Subterranean Fishes. p. 65-80. In: E. Trajano; M.E. Bichuette and B.G. Kapoor (eds), Biology of subterranean fishes. Enfield, Science Publ.

BRASIL. 1990. Decreto-Lei $n^{\circ}$. 99.556, de $1^{\circ}$ de outubro de 1990. Dispóe sobre a proteçáo das cavidades naturais subterrâneas existentes no território nacional, e dá outras providências. Brasília: Diário Oficial [da República Federativa do Brasil]. Available at http://www.planalto.gov. br/ccivil_03/decreto/1990-1994/D99556.htm. Accessed on 2 July 2015.

BRASIL. 2008. Decreto-Lei $n^{\circ}$. 6640, de 7 de novembro de 2008. Dá nova redaçáo aos arts. $1^{\circ}, 2^{\circ}, 3^{\circ}, 4^{\circ} \mathrm{e} 5^{\circ}$ e acrescenta os arts. 5- $A$ e 5-B ao Decreto no 99.556, de $1^{\circ}$ de outubro de 1990, que dispóe sobre a proteção das cavidades naturais subterrâneas existentes no território nacional. Brasília: Diário Oficial [da República Federativa do Brasil]. Available at http://www.planalto.gov.br/ccivil_03/_Ato20072010/2008/Decreto/D6640.htm. Accessed on 2 July 2015.
Budde-Lund, G. 1893. Landisopoder fra Venezuela, insamlede of Dr. F. Meinert. Entomologiske Meddelelser, 4: 111-129.

Budde-Lund, G. 1908. Isopoda von Madagaskar und Ostafrika mit Diagnosen verwandter Arten. p. 265-308, pls 12-18.In: A. Voeltzkow (ed), Reise in Ostafrikain den Jahren 1903-1905, Wissenschaftliche Ergebnisse, Vol. 2. Stuttgart, Wissenschaftliche Ergebnisse.

Campos-Filho, I.S. and Araujo, P.B. 2011. New species of Benthana Budde-Lund, 1908 (Crustacea: Oniscidea: Philosciidae) from Paraná. Brazil. Zootaxa, 2765: 38-46.

Campos-Filho, I.S.; Araujo, P.B.; Bichuette, M.E.; Trajano, E. and Taiti, S. 2014. Terrestrial isopods from Brazilian caves. Zoological Journal of the Linnean Society, 172: 360-425.

Campos-Filho, I.S.; Costa, S.L.N. and Araujo, P.B. 2013. Two new species of Benthana Budde-Lund, 1908 (Crustacea: Isopoda: Philosciidae) from Brazil. Tropical Zoology, 26(1): $1-14$.

Campos-Filho, I.S.; Taiti, S. and Araujo, P.B. 2015. Taxonomic revision of the genus Benthana Budde-Lund, 1908 (Isopoda: Oniscidea: Philosciidae). Zootaxa, 4022(1): $1-73$.

Cardoso, G.M.; Araujo, P.B.; Bueno, A.A.P. and Ferreira, R.L. 2014. Two new subterranean species of Hyalella Smith, 1874 (Crustacea: Amphipoda: Hyalellidae) from Brazil. Zootaxa, 3814(3): 353-368.

Cordeiro, L.M.; Borghezan, R. and Trajano, E. 2014. Subterranean biodiversity in the Serra da Bodoquena karst area, Paraguay River basin, Mato Grosso do Sul, Southwestern Brazil. Biota Neotropica, 14(3): 1-28.

Costa, S.L.N.; Campos-Filho, I.S. and Araujo, P.B. 2014. New species and new records of Benthana Budde-Lund, 1908 (Isopoda: Oniscidea: Philosciidae) from southern Brazil. Papéis Avulsos de Zoologia, 54(14): 169-176.

Dollfus, A. 1896. Recherches zoologiques dans les serres du Muséum de Paris. III. Crustacés isopodes terrestres. Feuille des jeunes Naturalistes, 31: 93-94.

Fiori, A.P. and Gaspar, L.A. 1993. Consideraçôes sobre a estratigrafia do Grupo Açungui (Proterozóico Superior), Paraná, sul do Brasil. Boletin IG-USP, Série Cientifica, 24: 1-19.

Fišer, C.; Zagmajster, M. and Ferreira, R.L. 2013. Two new Amphipod families recorded in South America shed light on an old biogeographical enigma. Systematics and Biodiversity, 11(2): 117-139.

Geoffroy M. Saint-Hilaire. 1810. Sur les Phyllostomes et les Mégadermes, deux genres de la famille des Chauvesouris. In: G. Dufour (ed), Annales du Museum d'Histoire Naturelle, Vol. 15. Paris, G. Dufour et Compagnie.

Juan, C.; Guzik, M.T.; Jaume, D. and Cooper, S.B. 2010. Evolution in caves: Darwin's 'wrecks of ancient life' in the molecular era. Molecular Ecology, 19(18): 3865-3880.

Lemos de Castro, A. 1964. Trichorhina heterophthalma, nueva especie de isopodo terrestre cavernicola de Cuba. Poeyana, Serie A, 2: 1-7. 
Lemos de Castro, A. 1971. Isopodos terrestres introduzidos no Brasil (Isopoda, Oniscoidea). Boletim do Museu Nacional, Nova Serie, Zoologia, 282: 1-14.

Nascimento, E.R.; Reis Neto, J.M. and Rebelo, A.M.A. 2010. Aplicação do índice de concentração da rugosidade do relevo no entendimento do nível de exposição dos sistemas cársticos ocorrentes na região norte do município de Curitiba, PR. Revista Brasileira de Geomorfologia, 11(2): 61-68.

Schmalfuss, H. 1998. Evolutionary strategies of the antennae in terrestrial isopods. Journal of Crustacean Biology, 18(1): 10-24.

Schmalfuss, H. 2003. World catalog of terrestrial isopods (Isopoda: Oniscidea). Stuttgarter Beiträge zur Naturkunde, 654: 1-341.

Schmidt, C. 2002. Contribution to the phylogenetic system of the Crinocheta (Crustacea, Isopoda). Part 1 (Olibrinidae to Scyphaidae s. str.). Mitteilungen aus dem Museum fur Naturkunde in Berlin, 78: 275-352.

Souza-Kury, L.A. 1993. Notes on Trichorhina I. Two new species from northeastern Brazil (Isopoda, Oniscidea, Platyarthridae). Revue Suisse de Zoologie, 100: 157-210.

Souza-Kury, L. 1998. Malacostraca. Peracarida. Isopoda. Oniscidea. p. 653-674. In: P.S. Young (ed), Catalogue of Crustacea of Brazil. Rio de Janeiro: Museu Nacional.

Souza, L.A.; Araújo, J.P. and Campos-Filho, I.S. 2011. The genus Trichorhina Budde-Lund in Brazil, with description of seven new species (Isopoda, Oniscidea, Platyarthridae). Iheringia, Série Zoologia, 101(3): 239-261.

Souza, L.A.; Bezerra, A.V. and Araújo, J.P. 2006. The first troglobitic species of Scleropactidae from Brazil (Crustacea, Isopoda, Oniscidea). Subterranean Biology, 4: 37-43.

Souza, L.A.; Ferreira, R.L. and Senna, A.R. 2015. Amphibious shelter-builder Oniscidea species from the New World with description of a new subfamily, a new genus and a new species from Brazilian Cave (Isopoda, Synocheta, Styloniscidae). PLoS One, 10(5): e0115021.

Souza, L.A.; Senna, A.R. and Kury, A.B. 2010. A new species and first record of Gabunillo Schmalfuss \& Ferrara, 1983 (Isopoda, Oniscidea, Armadillidae) from the Neotropics. Zootaxa, 2677: 1-14.

Spix, J.B. von. 1823. Simiarum et Vespertilionum Brasiliensium species novae, ou histoire naturelle des espèces nouvelles de singes et de chauves-souris, observés et recueillies pendant le voyage dans l'interieur du Brésil exécuté par ordre de S. M. le Roi de Bavière dans les années 1817-1820. Monachii, F.S. Hübschmanni.

Tabacaru, I. and Giurginca, A. 2013. Cavernicolous Oniscidea of Romania. Travaux de l'Institut de Speologie "Emile Racovitza”, t. LII: 3-26.

Taiti, S. 2004. Crustacea: Isopoda: Oniscidea (woodlice). p. 547-551. In: J. Gunn (ed), Encyclopedia of caves and karst science. New York, Fitzroy Dearborn, Taylor and Francis Group.

Taiti, S. 2014. New subterranean Armadillidae (Crustacea, Isopoda, Oniscidea) from Western Australia. Tropical Zoology, 27(4): 153-165.

Taiti, S. and Gruber, G.A. 2008. Cave-dwelling terrestrial isopods from Southern China (Crustacea, Isopoda, Oniscidea), with descriptions of four new species. In: L. Latella and R. Zorzin (eds), Research in South China karsts. Memorie del Museo Civico di Storia Naturale di Verona, Monografie Naturalistiche, 3: 101-123.

Taiti, S. and Xue, Z. 2012. The cavernicolous genus Trogloniscus nomem novum, with descriptions of four new species from southern China (Crustacea, Oniscidea, Styloniscidae). Tropical Zoology, 25(4): 183-209.

Taiti, S. and Wynne, J.J. 2015. The terrestrial Isopoda (Crustacea, Oniscidea) of Rapa Nui (Easter Island), with descriptions of two new species. Zookeys, 515: 27-49.

Van Name, W. 1940. A supplement to the American land and freshwater isopod Crustacea. Bulletin of the American Museum of Natural History, 77: 109-142.

Vandel, A. 1952. Étude des isopodes terrestres récoltés au Vénézuela par le Dr. G. Marcuzzi. Memorie del Museo Civico di Storia Naturale di Verona, 3: 59-203.

Vandel, A. 1962. Isopodes terrestres (Deuxième Partie). p. 417-931. In: Fédération Française des Sociétes de Sciences Naturelles (ed), Faune de France, 66. Paris, P. Lechevalier.

Verhoeff, K. 1949. Uber Land-Isopoden aus der Turkei. III. Istanbul Universitesi Fen Fakultesi Mecmuasi, Serı B, 14: $21-48$.

Wilkens, H. and Strecker, U. 2003. Convergent evolution of the cave fish Astyanax (Characidae, Teleostei): genetic evidence from reduced eye-size and pigmentation. Biological Journal of the Linnean Society, 80(4): 545-554. 